\title{
The Hemodynamic Effects of the Formulation of Glyphosate-Surfactant Herbicides
}

\author{
Hsin-Ling Lee and How-Ran Guo \\ National Cheng Kung University \\ Taiwan
}

\section{Introduction}

\subsection{Epidemiology of Glyphosate poisoning in Taiwan and other countries}

Glyphosate ([N-(phosphonomethyl) glycine], CAS Number 1017-83-6) is the active ingredient of Roundup ${ }^{\circledR}$, a common nonselective weed control agent. A variety of glyphosate-based formulations are registered in many countries under different brand names. The glyphosate-surfactant herbicide (GlySH) is usually a formulated commercial product containing glyphosate salts, such as isopropylamine, diammonium, potassium, trimesium, or sesquisodium salt. A GlySH commonly used in Taiwan contains $41 \%$ glyphosate as the isopropylamine salt (CAS Number 38641-94-0), water, and a variable amount of surfactant. The main surfactant used in GlySH products worldwide is polyoxyethyleneamine (CAS Number 61791-26-2). GlySH, an alternative to paraquat, has been used in suicide attempts in Taiwan and many countries in the Asia-Pacific region (Sawada et al., 1988; Menkes et al., 1991; Tominack et al., 1991; Talbot et al., 1991; Hung et al., 1997; Lee et al., 2000; Stella and Ryan, 2004; van der and Konradsen, 2006; Lee et al., 2008; Roberts et al., 2010). The case fatality rates were around 1.9 to $16 \%$ (Sawada et al., 1988; Tominack et al., 1991; Talbot et al., 1991; Hung et al., 1997; Lee, et al., 2000; Suh et al., 2007), and a large study by the Poison Control Center (PCC) of Taiwan, which included 2186 cases of GlySH poisoning from 1986-2007, reported a case fatality rate of 7.2\% (Chen et al., 2009). However, a much higher fatality rate up to $29.3 \%$ has been found in a recent study (Lee et al., 2008). Obviously, it continues to be a public health problem that calls for concerns.

\subsection{Metabolism of glyphosate}

Glyphosate is a nonselective herbicide that inhibits plant growth through interference with the production of essential aromatic amino acids by inhibition of the enzyme enolpyruvylshikimate phosphate synthase, which is responsible for the biosynthesis of chorismate, an intermediate in phenylalanine, tyrosine, and tryptophan biosynthesis (Williams et al., 2000). The absence of this biosynthetic pathway in mammals may explain the relatively low systemic toxicity of glyphosate (oral median lethal dose [LD50] for rats $4,320 \mathrm{mg} / \mathrm{kg}$, rabbits 3,800 mg/ kg) (Smith and Oehme, 1992). In the terrestrial environment, glyphosate is mainly biodegraded to aminomethylphosphonic acid (AMPA) when metabolized by bacterial in soils (Rueppel et al., 1977). According to the animal study in Sprague-Dawley rats, approximately $35-40 \%$ of the administered dose was absorbed from 
the gastrointestinal tract, and urine and feces were equally important routes of elimination after one oral dose $(10 \mathrm{mg} / \mathrm{kg}$ ) (Brewster et al., 1991). The animal study indicated that virtually no toxic metabolites of glyphosate were produced when it was administrated orally and that there was little evidence of metabolism (Müller et al., 1981). Essentially 100\% of the body burden was the parent compound (Müller et al., 1981).

\subsection{Systemic toxic syndrome of GlySH poisoning}

Although GlySH is considered to be only slightly toxic to rats, ingestion of a substantial volume of GlySH has been reported to be associated with toxic effects, including gastrointestinal injury, laryngeal injury, pulmonary toxicity, impaired renal and liver functions, leukocytosis, impaired neurological function, dermatitis, metabolic acidosis, arrhythmias, myocardial depression, shock, and even death in humans (Sawada et al., 1988; Talbot et al., 1991; Tominack et al., 1991; Hung et al., 1997; Lin et al., 1999; Lee et al., 2000; Lee et al., 2008; Roberts et al., 2010). Although symptoms and signs of various organ systems could be seen clinically, the definite mechanism of systemic toxic syndrome in acute GlySH poisoning is still unclear. Aspiration pneumonitis and upper respiratory tract irritation are commonly reported findings (Tominack et al., 1991; Talbot et al., 1991; Hung et al., 1997). Hung et al. (1997) strongly suspected that severe laryngeal injury is the primary mechanism of respiratory aspiration and the leading cause of morbidity and mortality following GlySH intoxication. Previous animal studies in rats showed that intratracheal administration of GlySH produced more severe lung damages than oral administration (Martinez and Brown, 1991; Adam et al., 1997). They implied that at least some of the clinical manifestations are related to an aspiration complication. However, pulmonary hemorrhage and other systemic insults could also be seen in animals with oral administration of various components of GlySH (Martinez et al., 1990). Other mechanisms should be considered in explaining the impacts of GlySH on pulmonary and other systems.

\subsection{The toxic mechanism of glyphosate and GlySH on mitochondria}

Uncoupling of mitochondrial oxidative phosphorylation on rat liver mitochondria has been proposed as a lesion in glyphosate poisoning (Bababunmi et al., 1979; Olorunsogo et al., 1979a). These animal studies showed that the respiratory control ratios of liver mitochondria and state 3 respiration were significantly reduced. Enzyme inhibition of the Kreb's cycle and the uncoupling effect were also shown in the study of plant's mitochondria (Olorunsogo et al., 1979b; Olorunsogo et al., 1980). A study also showed that glyphosate enhanced mitochondrial ATPase with dose-dependent response (Olorunsogo et al., 1979b). The evidences suggested that glyphosate is an uncoupler of electron transport chain. In the study by Olorunsogo (1990), glyphosate significantly increased the permeability of the mitochondrial membrane to protons and to $\mathrm{Ca}^{2+}$ in liver mitochondria, and the author suggested that glyphosate may be able to act both as a chelator and a mild protonophore. The author also found that glyphosate had an inhibitive effect on energy-dependent transhydrogenase reaction in isolated rat liver mitochondria (Olorunsogo, 1982). In rats given glyphosate intragastrically for 2 weeks, glyphosate decreased the hepatic level of cytochrome P450 and monooxygenase activities, as well as the intestinal activity of aryl hydrocarbon hydroxylase (Hietanen et al., 1983). Even though most of the above studies claimed that glyphosate was tested, but actually used the isopropylamine salt of glyphosate (IPAG) (Bababunmi et al., 1979; Olorunsogo et al., 1979b; Olorunsogo, 1982; Hietanen et al., 
1983), those studies still implied that mitochondria may be a critical target in the toxic mechanisms of GlySH. However, the clinical significance of the relationship between these biochemical abnormalities and the systemic toxic syndrome is unclear. Further investigation should be conducted to clarify the possible toxic mechanisms in animal and human GlySH intoxication.

\section{Studies for GlySH poisoning}

It is within the context of the above background information that the two studies were undertaken. We first conducted a retrospective case-control study in a medical center to identify predictors of GlySH poisoning related fatality. On the basis of our data, among the clinical symptoms that GlySH intoxicated patients may present, the toxic symptoms on the cardiovascular system interested us. We then established an animal model to study the cardiovascular effects induced by each component of GlySH formulation, clarifying which one is responsible for the toxic symptoms.

\section{Clinical outcomes and predictors of GlySH poisoning related fatality}

In this section, we describe a retrospective case-control study accessing clinical outcomes and identifying the predictors of GlySH poisoning related fatality.

\subsection{Study design}

This was a retrospective study of patients with GlySH poisoning presenting to the emergency department (ED) of a referral center in a large agricultural area with approximately 2 million residents in southern Taiwan over a seven-year period. The ED's annual patient visits census is about 51,000. All the medical records of patients with GlySH poisoning following oral ingestion who presented to the ED of the referral center from June 1988 to December 1995 were reviewed.

\subsection{Study protocol}

We collected data on the date of admission, age, sex, estimated amount of GlySH ingested, co-ingestants of other agrochemicals, ethanol, or pharmaceuticals, suicide attempts, out-of hospital interval, initial clinical presentation, initial laboratory data in the ED, and clinical course. Laboratory variables that were reviewed included arterial blood gas (ABG), blood urea nitrogen (BUN), creatinine, alanine aminotransferase (ALT), aspartate aminotransferase (AST), bilirubin, sodium, potassium, calcium, phosphate, white blood cell (WBC) count, hematocrit, platelet, urine analysis, chest x-ray (CXR), and electrocardiogram (ECG). Only the laboratory studies done immediately upon the patients' arrival were taken into consideration. There were some patients who had received first aid and were then transferred from other EDs. For these patients, we used the primary data from those EDs. For clinical and statistical consideration, patients whose serum $\mathrm{pH}$ values $<7.35$ on the ABG were considered to be "acidotic." Of note, the clinical practice at this hospital was to routinely obtain toxicological screens of other pesticides, such as paraquat and organophosphates, and screens of benzodiazepines.

We also performed specific tests according to the history offered by patients themselves, friends, or family members. The amount ingested was usually given in descriptive terms such as "a mouthful," "a small cup," or "half a bottle." For statistical purposes, we assigned 
a volumetric value to each description: $5 \mathrm{~mL}$ for "a little" or "a spoon," $25 \mathrm{~mL}$ for "a mouthful," and $100 \mathrm{~mL}$ for "a small cup." If the patient said "a bottle," the size was identified as being $150 \mathrm{~mL}, 300 \mathrm{~mL}, 500 \mathrm{~mL}$, or 1 liter, according to the brand, empty bottles carried by family members or friends, or the description by family members or friends.

\subsection{Data analysis}

All analysis was performed using SPSS statistical software Version 6.03 (SPSS Inc., Chicago, IL). For univariate analysis, we used the Student $t$ and Wilcoxon tests for continuous variables and the chi-square and Fisher's exact tests for categorical variables. We also calculated the odds ratio (OR) and associated 95\% confidence interval (C.I.) for each variable. A p-value of less than 0.05 was considered statistically significant. Variables with ORs more than 5 were considered to be major prognostic predictors. All major prognostic variables were further evaluated by multiple logistic regression analyses with the stepwise approach. A patient's probability of survival (Ps) could then predicted using the logistic regression model Ps $=1 /\left(1+\mathrm{e}^{-\mathrm{b}}\right)$ where $b=b_{0}+b_{1} \times$ risk factor $I+b_{2} \times$ risk factor II $+b_{3} \times$ risk factor III $\ldots+b_{\mathrm{N}} \times$ risk factor $\mathrm{N}$.

\subsection{Results}

From June 1988 to December 1995, 131 patients presented to the hospital with GlySH ingestion, including 69 men and 62 women. There were 11 fatalities, yielding a fatality rate of $8.4 \%$. The most common presentations included sore throat, nausea (with or without vomiting), and fever (Table 1).

Table 2 shows the initial laboratory data of patients. The most common laboratory abnormalities included leukocytosis (WBC count > 104/uL; 85/125, 68\%), lowered bicarbonate $\left(\mathrm{HCO}_{3}<22 \mathrm{mEq} / \mathrm{L} ; 39 / 81,48.1 \%\right.$ ), acidosis (serum $\mathrm{pH}<7.35,29 / 81,35.8 \%$ ), elevated AST (> $40 \mathrm{U} / \mathrm{L} ; 32 / 108,33.6 \%$ ), hypoxemia (PO2 < 60 torr while breathing room air; 23/81, 28.4\%), and elevated BUN (> $21 \mathrm{mg} / \mathrm{dL} ; 21 / 123,17.1 \%$ ).

Of the 81 patients who had 12-lead electrocardiograms, 15 showed abnormal findings. The most frequent abnormalities were sinus tachycardia and nonspecific ST-T changes. Of 29 the patients who had serum $\mathrm{pH}<7.35,13$ had metabolic acidosis, 1 had respiratory acidosis, and 15 had mixed-type acidosis. Of the 105 patients who had CXR, 22 revealed abnormal infiltrates or patches. Three patients had renal failure that necessitated hemodialysis, and all resulted in fatalities. Seven patients had co-ingestants, including sedative drugs (2), hypnotics (3), wine (3), and paraquat (1). The average survival time of the fatality cases was $2.8 \pm 0.8$ days.

Comparisons of clinical variables and laboratory data on arrival between survivors and fatalities are presented in Tables 1 and 2. The mean \pm standard errors of the means (SEM) age of the survivors was $47 \pm 2$ years, while that of the fatalities was $60 \pm 4$ years $(p=0.02$ ). No difference was found in the distributions of genders. The estimated amount of GlySH ingested averaged $122 \pm 12 \mathrm{~mL}$ among the survivors and $330 \pm 42 \mathrm{~mL}$ among the fatalities ( $\mathrm{p}$ $<0.001$ ). The mean out-of-hospital time among the survivors was longer than that in fatalities (Table 1), but the difference was not statistically significant.

Of the 17 variables identified as major prognostic predictors (Table 3), respiratory distress necessitating intubation, respiratory distress, renal dysfunction necessitating hemodialysis, abnormal CXR, shock, larger amount of ingestion (> $200 \mathrm{~mL})$, altered consciousness, hyperkalemia, and pulmonary edema were associated with the largest ORs. Only the cases 


\begin{tabular}{|c|c|c|c|c|}
\hline Variable & $\begin{array}{l}\text { Survivors } \\
(\mathrm{n}=120)(\%)\end{array}$ & $\begin{array}{l}\text { Fatalities } \\
(\mathrm{n}=11)(\%)\end{array}$ & $\begin{array}{c}\text { Total } \\
(\mathrm{n}=131)(\%)\end{array}$ & $p^{\mathrm{b}}$ \\
\hline Age (year) ${ }^{a}$ & $47 \pm 2$ & $60 \pm 4$ & $48 \pm 2$ & $0.02 *$ \\
\hline Gender (male/female) & $62 / 58$ & $7 / 4$ & 69 / 62 & 0.47 \\
\hline Out-of-hospital interval (hr) ${ }^{a}$ & $4.0 \pm 0.5$ & $2.2 \pm 0.4$ & $3.8 \pm 0.4$ & 0.57 \\
\hline $\begin{array}{l}\text { Estimated Ingested Amount } \\
(\mathrm{mL})^{\mathrm{a}}\end{array}$ & $122 \pm 12$ & $330 \pm 42$ & $138 \pm 12$ & $<0.001^{*}$ \\
\hline Fever & $48 / 120(40.0)$ & 6/11 (54.5) & $54 / 131(41.2)$ & 0.36 \\
\hline Nausea and/or vomiting & $88 / 118(74.6)$ & $5 / 8(62.5)$ & $93 / 126(73.8)$ & 0.43 \\
\hline Sore throat & 96/118 (81.4) & $5 / 9(55.6)$ & $101 / 127(79.5)$ & 0.08 \\
\hline Diarrhea & $25 / 120(21.0)$ & $1 / 10(9.1)$ & 26/131 (19.1) & 0.69 \\
\hline Respiratory distress & $19 / 120(15.8)$ & $11 / 11(100.0)$ & $30 / 131(22.9)$ & $<0.001^{*}$ \\
\hline Altered consciousness & 19/120 (15.8) & 10/11 (90.9) & 29/131 (21.3) & $<0.001^{*}$ \\
\hline $\begin{array}{l}\text { Respiratory distress } \\
\text { necessitating intubation }\end{array}$ & $7 / 120(5.8)$ & $11 / 11(100.0)$ & 18/131 (13.7) & $<0.001^{*}$ \\
\hline Pulmonary edema & $2 / 119(4.2)$ & $4 / 11(36.4)$ & 6/130 (4.6) & $<0.001^{*}$ \\
\hline Abnormal CXR & 15/98 (15.3) & $7 / 7(100)$ & 22/105 (21.0) & $<0.001^{*}$ \\
\hline Shock & $5 / 119(4.2)$ & 8/11 (72.7) & 13/130 (10.0) & $<0.001^{*}$ \\
\hline Dysrrhythmia & 9/71 (12.7) & 6/10 (75.0) & $15 / 81(18.5)$ & $<0.001^{*}$ \\
\hline $\begin{array}{l}\text { Renal dysfunction } \\
\text { necessitating hemodialysis }\end{array}$ & $0 / 120(0.0)$ & 3/11 (27.0) & $3 / 131(27.0)$ & $<0.001^{*}$ \\
\hline Suicide attempt & $105 / 120(17.5)$ & $11 / 11(100.0)$ & 116/131 (88.5) & 0.36 \\
\hline
\end{tabular}

aData are expressed as mean \pm standard errors of the means.

$\mathrm{bP}$ values are for comparisons between survivors and fatalities.

${ }^{*} p<0.05$ is significant.

Data from Lee et al, 2000.

Table 1. Clinical variables on arrival at the emergency department among patients.

with complete data were used for the multiple logistic regression analysis, and we identified three significant independent predictors of survival, which could be applied to construct a logistic regression model as follows:

$$
\begin{gathered}
\text { Ps }=1 /\left(1+\mathrm{e}^{-\mathrm{b}}\right) \\
\mathrm{b}=-216.93-5.10 \times[\text { acute pulmonary edema }]-1.80 \times[\mathrm{K}]+31.26 \times[\mathrm{pH}]
\end{gathered}
$$

Using Ps $=0.25$ as the cutoff for predicting fatalities, we obtained a sensitivity of $100 \%$ and a specificity of $95.7 \%$. Because pulmonary edema is a binary response, the above formula can be simplified as the following:

1. When pulmonary edema is absent, $31.26 \times[\mathrm{pH}]-1.80 \times[\mathrm{K}]<215.83$ predicts fatality.

2. When pulmonary edema is present, $31.26 \times[\mathrm{pH}]-1.80 \times[\mathrm{K}]<220.93$ predicts fatality. 


\begin{tabular}{|c|c|c|c|}
\hline Variables & $\begin{array}{c}\text { Survivors } \\
(\mathrm{n}=120)\end{array}$ & $\begin{array}{l}\text { Fatalities } \\
(\mathrm{n}=11)\end{array}$ & $p$ \\
\hline \multicolumn{4}{|l|}{ Complete blood count } \\
\hline $\mathrm{WBC}\left(10^{4} / \mathrm{uL}\right)$ & $13.4 \pm 0.5$ & $18.5 \pm 2.5$ & $<0.01^{*}$ \\
\hline Hematocrit (\%) & $42.0 \pm 0.5$ & $45.3 \pm 1.5$ & 0.07 \\
\hline Platelet count $\left(10^{3} / \mathrm{cmm}^{3}\right)$ & $265 \pm 9$ & $239 \pm 30$ & 0.39 \\
\hline \multicolumn{4}{|l|}{ Biochemical data } \\
\hline Urea nitrogen $(\mathrm{mg} / \mathrm{dL})$ & $16 \pm 1$ & $19 \pm 3$ & 0.26 \\
\hline Creatinine $(\mathrm{mg} / \mathrm{dL})$ & $1.0 \pm 0.1$ & $1.4 \pm 0.2$ & $<0.01^{*}$ \\
\hline Sodium (mmol/L) & $141 \pm 1$ & $141 \pm 2$ & 0.87 \\
\hline Potassium (mmol/L) & $3.8 \pm 0.1$ & $4.7 \pm 0.4$ & 0.06 \\
\hline Chloride (mmol/L) & $105 \pm 1$ & $103 \pm 4$ & 0.74 \\
\hline Total calcium (mg/dL) & $9.1 \pm 0.1$ & $9.0 \pm 0.2$ & 0.79 \\
\hline Phosphate (mg/dL) & $3.4 \pm 0.1$ & $3.9 \pm 0.9$ & 0.56 \\
\hline Total bilirubin (mg/dL) & $1.0 \pm 0.1$ & $1.2 \pm 0.4$ & 0.99 \\
\hline $\operatorname{ALT}(\mathrm{U} / \mathrm{L})$ & $35 \pm 3$ & $64 \pm 21$ & 0.20 \\
\hline AST (U/L) & $37 \pm 3$ & $110 \pm 44$ & 0.13 \\
\hline \multicolumn{4}{|l|}{ Arterial blood gases } \\
\hline $\mathrm{pH}$ & $7.39 \pm 0.01$ & $7.17 \pm 0.05$ & $<0.001^{*}$ \\
\hline $\mathrm{PO}_{2}(\mathrm{mmHg})$ & $75.3 \pm 2.6$ & $48.2 \pm 7.2$ & $<0.001^{*}$ \\
\hline $\mathrm{PCO}_{2}(\mathrm{mmHg})$ & $36.8 \pm 0.8$ & $41.8 \pm 4.5$ & 0.65 \\
\hline $\mathrm{HCO}_{3}^{-}(\mathrm{mEq} / \mathrm{L})$ & $22 \pm 1$ & $15 \pm 2$ & $<0.001^{*}$ \\
\hline
\end{tabular}

Data are expressed as means $\pm \mathrm{SEM}$, and ${ }^{*} p<0.05$ is significant. $\mathrm{WBC}=$ white blood cell; $\mathrm{ALT}=$ alanine aminotransferase, $\mathrm{AST}=$ aspartate aminotransferase.

Data from Lee et al, 2000.

Table 2. Initial laboratory data of the patients.

\subsection{Conclusion and discussion}

\subsubsection{Clinical presentations of GlySH poisoning}

Clinical presentations of GlySH poisoning varied across studies (Sawada and Nagai, 1987; Kawamura et al., 1987; Sawada et al.,, 1988; Talbot et al., 1991; Tominack et al., 1991; Menkes et al. 1991). An analysis of three retrospective reviews of 246 cases (Sawada et al., 1988; Talbot et al., 1991; Tominack et al., 1991) revealed that patients most frequently presented with nausea and/or vomiting (40\%), abdominal pain, and diarrhea (12\%) initially, followed by sore throat $(41-43 \%)$, fever $(7 \%)$, gastrointestinal mucosal damage (7-43\%), transient renal (10-14\%) and hepatic (19-40\%) dysfunction, metabolic acidosis, pulmonary edema (5$13 \%)$, shock $(9 \%)$, and death $(10.5-16.7 \%)$. In our study, nausea with or without vomiting (73.8\%), sore throat $(79.5 \%)$, and fever $(41.2 \%)$ were the most common initial manifestations. We found leukocytosis $(68.0 \%)$, low bicarbonate (48.1\%), acidosis (35.8\%), hepatic 


\begin{tabular}{|c|c|c|c|c|}
\hline Predictors & $\begin{array}{l}\text { Fatalities } \\
(\mathrm{n}=11)\end{array}$ & $\begin{array}{l}\text { Survivors } \\
(\mathrm{n}=120)\end{array}$ & $\begin{array}{c}\text { Total } \\
(\mathrm{n}=131)\end{array}$ & $\begin{array}{l}\text { Odds Ratio } \\
(95 \% \text { C.I. })\end{array}$ \\
\hline $\begin{array}{l}\text { Respiratory distress necessitating } \\
\text { intubation }\end{array}$ & $11 / 11$ & $7 / 120$ & $\begin{array}{l}18 / 131 \\
(13.7 \%)\end{array}$ & $\begin{array}{c}348.1 \\
(98.8-\infty)^{*}\end{array}$ \\
\hline Respiratory distress & $11 / 11$ & $19 / 120$ & $\begin{array}{l}30 / 131 \\
(22.9 \%)\end{array}$ & $\begin{array}{c}119.7(29.6- \\
484.6)^{*}\end{array}$ \\
\hline $\begin{array}{l}\text { Renal failure necessitating } \\
\text { hemodialysis }\end{array}$ & $3 / 11$ & $0 / 120$ & $\begin{array}{l}3 / 131 \\
(2.3 \%)\end{array}$ & $\begin{array}{l}99.2(26.4- \\
372.4)^{*}\end{array}$ \\
\hline Abnormal CXR & $7 / 7$ & $15 / 98$ & $\begin{array}{l}22 / 105 \\
(21.0 \%)\end{array}$ & $\begin{array}{l}80.8(18.2- \\
359.0)^{*}\end{array}$ \\
\hline Shock (SBP $<90 \mathrm{mmHg}$ ) & $8 / 11$ & $5 / 119$ & $\begin{array}{l}13 / 130 \\
(10.0 \%)\end{array}$ & $\begin{array}{c}60.8(10.1- \\
435.8)^{\dagger}\end{array}$ \\
\hline $\begin{array}{l}\text { Larger amount of ingestion }(>200 \\
\mathrm{ml})\end{array}$ & $9 / 10$ & $17 / 101$ & $\begin{array}{l}26 / 128 \\
(20.3 \%)\end{array}$ & $\begin{array}{c}53.5(13.6- \\
210.9)^{\dagger}\end{array}$ \\
\hline Altered consciousness & $10 / 11$ & $19 / 120$ & $\begin{array}{l}29 / 131 \\
(22.1 \%)\end{array}$ & $\begin{array}{l}53.2(13.6- \\
207.5)^{*}\end{array}$ \\
\hline Hyperkalemia $([\mathrm{K}]>5.5 \mathrm{mmol} / \mathrm{L})$ & $4 / 10$ & $2 / 118$ & $\begin{array}{l}6 / 128 \\
(4.7 \%)\end{array}$ & $\begin{array}{l}38.7(4.6- \\
398.6)^{\dagger}\end{array}$ \\
\hline Pulmonary edema & $4 / 11$ & $2 / 119$ & $\begin{array}{l}6 / 130 \\
(4.6 \%)\end{array}$ & $\begin{array}{c}33.4(4.1- \\
330.7)^{\dagger}\end{array}$ \\
\hline Elevated creatinine (> $1.5 \mathrm{mg} / \mathrm{dL})$ & $4 / 11$ & $4 / 116$ & $\begin{array}{l}8 / 127 \\
(6.3 \%)\end{array}$ & $\begin{array}{c}16.0(2.6- \\
103.3)^{\dagger}\end{array}$ \\
\hline $\begin{array}{l}\text { Lowered bicarbonate }\left(\mathrm{HCO}_{3}^{-}<22\right. \\
\text { meq/L) }\end{array}$ & $10 / 11$ & $29 / 70$ & $\begin{array}{c}39 / 81 \\
(48.1 \%)\end{array}$ & $\begin{array}{c}14.1(1.7- \\
311.2)^{\dagger}\end{array}$ \\
\hline Acidosis $(\mathrm{pH}<7.35)$ & $9 / 11$ & $20 / 70$ & $\begin{array}{c}29 / 81 \\
(35.8 \%)\end{array}$ & $\begin{array}{l}11.3(1.98- \\
83.3)^{\dagger}\end{array}$ \\
\hline Dysrrhythmia & $6 / 10$ & $9 / 71$ & $\begin{array}{c}15 / 81 \\
(18.5 \%)\end{array}$ & $10.3(2.0-56.5)^{\dagger}$ \\
\hline $\begin{array}{l}\text { Hyperphosphatemia }([\mathrm{P}]>5.0 \\
\mathrm{mg} / \mathrm{dL})\end{array}$ & $2 / 10$ & $3 / 95$ & $\begin{array}{l}5 / 105 \\
(4.8 \%)\end{array}$ & $7.7(6.8-71.4)^{\dagger}$ \\
\hline Elevated AST (> $40 \mathrm{U} / \mathrm{L})$ & $8 / 11$ & $32 / 108$ & $\begin{array}{l}40 / 119 \\
(33.6 \%)\end{array}$ & $6.3(1.4-32.5)^{\dagger}$ \\
\hline Hypoxemia $\left(\mathrm{PO}_{2}<60 \mathrm{mmHg}\right)$ & $7 / 11$ & $16 / 70$ & $\begin{array}{c}23 / 81 \\
(28.4 \%)\end{array}$ & $5.9(1.3-28.2)^{\dagger}$ \\
\hline Leukocytosis $\left(\mathrm{WBC}>10^{4} / \mathrm{uL}\right)$ & $10 / 11$ & $75 / 114$ & $\begin{array}{c}85 / 125 \\
(68 \%)\end{array}$ & $5.2(0.6-112.5)^{\dagger}$ \\
\hline
\end{tabular}

*Test-based $95 \%$ confidence interval for odds ratios.

†Cornfield's 95\% confidence interval for odds ratios.

Data from Lee et al, 2000.

Table 3. Major predictors associated with poor patient outcome (odds ratio > 5). 
dysfunction (33.6\%), hypercapnea (30.9\%), hypoxemia $(28.4 \%)$, and renal insufficiency $(17.1 \%)$ were the most common laboratory abnormalities. These findings were similar to previous reports of severe intoxications, except that our patients showed a higher prevalence of sore throat, nausea and/or vomiting, fever, acidosis, and diarrhea.

In this study, shock $(8 / 11,72.7 \%)$, respiratory distress necessitating intubation $(11 / 11$, $100 \%)$, pulmonary edema $(4 / 11,36.4 \%)$, dysrrhythmia $(6 / 10,75 \%)$, altered consciousness $(10 / 11,90.9 \%)$, and renal dysfunction necessitating hemodialysis $(3 / 11,27.0 \%)$ were major predictors of fatality. Recent studies involving larger numbers of cases also showed that shock, respiratory failure, altered consciousness, and oligouria were more common in the fatal GlySH exposures (Roberts et al., 2010; Chen et al., 2009).

\subsubsection{Predictors of GlySH poisoning}

In this study, we identified acute pulmonary edema, hyperkalemia, and acidosis as major predictors of poor outcome, which are compatible with most of glyphosate studies in Taiwan. The risk factors of fatality or severity of GlySH exposure have been studied and discussed over the years, including the amount of exposure, hypovolemic shock, intractable shock, Acute Physiology and Chronic Health Evaluation II score, age, male gender, laryngeal injury with aspiration, abnormal chest $\mathrm{X}$-ray, calendar time, reason for exposure, atropine therapy, elapsed time, delayed presentation, number of involved organs, metabolic acidosis, tachycardia, elevated serum creatinine, and high plasma glyphosate concentrations on admission (> $734 \mathrm{ug} / \mathrm{mL}$ ) (Sawada et al., 1988; Tominack et al., 1991; Talbot et al., 1991; Hung et al., 1997; Lee et al., 2000; Lee et al., 2008; Chen et al., 2009; Roberts et al., 2010). Prognostic predictors can help emergency staff in identifying patients who are expected to deteriorate or die. We recommend that all the patients who are reported to have ingested large amounts of GlySH be carefully observed, especially for those who present with severe respiratory distress, unstable hemodynamics, requiring hemodialysis, pulmonary edema, and old age. The risk of immediate death is much less likely if the patient has no such risk factors on presentation.

\section{Cardiovascular toxicity of GlySH poisoning}

\subsection{Presentation of cardiovascular toxicity in GlySH poisoning}

Cardiovascular involvement in GlySH intoxicated patients may include ECG abnormalities such as sinus tachycardia, sinus bradycardia, first degree AV block, as well as shock (Sawada et al., 1988; Talbot et al., 1991; Tominack et al., 1991). Shock is one of poor prognostic signs in severely intoxicated patients (Tominack et al., 1991; Sawada et al., 1988). Sawada and Nagai (1987) reported that shock might be due to intravascular hypovolemia, which responds to fluid resuscitation and vasopressor agents. However, the study by Talbot et al. (1991) did not support the hypovolemic shock because they found shock developed after rehydration. Lin et al. (1999) reported one patient who presented with cardiogenic shock with left-ventricular hypokinesis after drinking about $150 \mathrm{~mL}$ of GlySH. Ventricular tachycardia was observed during resuscitation, and the blood pressure responded to neither vasopressor agents nor fluid resuscitation. The patient gradually recovered in the following $16 \mathrm{~h}$, with the restoration of his left-ventricular function. In a beagle dog study, cardiac depression was observed by Roundup and surfactant injection (Tai et al., 1990). These data suggest that the suppression of the cardiac conduction system and contractility, rather than intravascular hypovolemia, plays an important role in the shock induced by acute GlySH 
poisoning in humans. However, the detailed mechanism of this cardiac involvement has not been demonstrated, not to mention the components responsible for these symptoms.

\subsection{The hemodynamic effects of the formulation of GlySH}

Because the acid form of glyphosate has low solubility in water ( $12 \mathrm{~g} / \mathrm{L})$, commercial compositions of glyphosate generally contain glyphosate salts such as isopropylamine (IPA) (CAS Number 75-31-0), diammonium, potassium, trimesium, or sesquisodium salt, in which the acidic glyphosate is neutralized with a base to form the salt and becomes more watersoluble than the glyphosate acid. IPA is a colorless, flammable liquid with a tangy, ammonia-like odor (NFPA, 1997) and is usually used in the synthesis of dyes, pharmaceuticals, insecticides, rubber chemicals, textile-processing agents and other surface active agents (Harbison, 1998). Its oral $\mathrm{LD}_{50}$ for rats is $820 \mathrm{mg} / \mathrm{kg}$ (Bingham E et al., 2001). In a study of mongrel dogs, an IPA injection showed positive dose-dependent inotropic and chronotropic responses, with increasing myocardial contraction, arterial pressure, and pulse pressure, as well as significantly reduced vascular resistance in the hind leg (Ishizaki et al., 1974). Another study showed that infusion of IPA $(2.5 \mathrm{mg} / \mathrm{kg}$ per min) produced an initial increase in arterial pressure and heart rate (HR), followed by prolonged hypotension and bradycardia, but lower doses produced only a hypotensive response (Privitera et al., 1982).

The surfactants commonly used in herbicide products serve several purposes, including acting as wetting agents, promoting uniform spread of the herbicide on the leaf surface, and assisting the penetration of glyphosate into the leaf (Bradberry et al., 2004). Polyoxyethyleneamine (POEA) is the surfactant commonly used in GlySH and has an oral $\mathrm{LD}_{50}$ of about $1200 \mathrm{mg} / \mathrm{kg}$ in rats (Williams et al., 2000), which is considerably more toxic than that of glyphosate itself (EPA, 1993). In human and animal studies, this nonionic polyoxyethylene alkyl group of surfactants is usually considered to be mainly or partly responsible for the toxic effects of various pesticides, inducing gastrointestinal tract, pulmonary, and depressive cardiac effects (Tai et al., 1990; Martinez and Brown, 1991; Koyama et al., 1994; Sawada et al., 1988; Adam et al., 1997). The clinical effects of other components used in GlySH, such as IPA or IPAG have rarely been studied and reported. Therefore, a study was conducted to characterize the major components leading to the cardiovascular failure in cases with GlySH poisoning.

\section{The comparative effects of the formulation of GlySH on hemodynamics}

In this section, we describe an animal experiment used for exploring the hemodynamic effects induced by the infusion of different components of GlySH formulation.

\subsection{Animal model}

We used male Landrace piglets (aged 6-8 weeks, body weight 8-15 kg) as the model for the study. The piglets were fasted for one day before surgery. Each piglet was initially sedated with an intramuscular injection of ketamine $\left(20-30 \mathrm{mg} / \mathrm{kg}\right.$; Ketalar ${ }^{\circledR} 50 \mathrm{mg} / \mathrm{mL}$, UBI Asia, Hsinchu, Taiwan) and atropine $(0.05 \mathrm{mg} / \mathrm{kg})$ and then placed in a supine position on a thermally controlled blanket on an operating table. A percutaneous venous cannula $(24 \mathrm{G})$ was placed into the piglet's marginal vein of the pinna, followed by an induction dose of propofol $(0.5 \mathrm{~mL} / \mathrm{kg}$ of $10 \mathrm{mg} / \mathrm{mL}$; Propoful 1\%, Fresenius Kabi, Austria) and pancuronium bromide (0.1 mg/kg; Pavulon ${ }^{\circledR} 4 \mathrm{mg} / 2 \mathrm{~mL}$, Organon International, Oss, Netherlands). The 
piglet was then intubated with an appropriately sized endotracheal tube (4.5-5.0; Mallinckrodt ${ }^{\circledR}$ endotracheal tubes, Nellcor, Boulder, CO). Mechanical ventilation was initiated with an infant ventilator (North American Drager Narcomed 2A; DRE Inc., Louisville, $\mathrm{KY})$ with oxygen gas $\left(50 \% \mathrm{FiO}_{2}\right)$ at a peak inspiratory pressure of $15 \mathrm{cmH}_{2} \mathrm{O}$, inspiratory time of $0.75 \mathrm{~s}$, a positive-end-expiratory-pressure of $5 \mathrm{cmH}_{2} \mathrm{O}$, and a respiratory rate of 12 breaths per min. We measured the ABG intermittently and adjusted the peak pressure to maintain normocapnia $\left(\mathrm{PaCO}_{2} 35-45 \mathrm{mmHg}\right)$ during the baseline period. Endtidal $\mathrm{CO}_{2}$ from the endotracheal humidity cuff was continuously monitored. Following intubation, the piglet was regularly paralyzed with intravenous pancuronium $(100 \mu \mathrm{g} / \mathrm{kg})$, and anesthesia was maintained with $2 \%-3 \%$ isoflurane $(250 \mathrm{~mL}$; Forane, Abbott Laboratories Ltd., Queenborough, Kent, UK). (Figure 1)

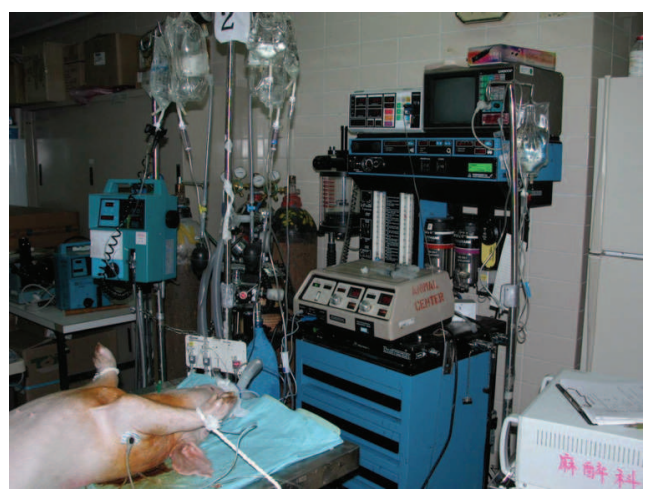

Fig. 1. Anesthesia and ventilator setting for experimental animals.

\subsection{Monitoring physiological variables}

We indwelled a rectal temperature probe for body temperature measurements and maintained the rectal temperature at $39.5-40.0{ }^{\circ} \mathrm{C}$ till the piglet was extubated. The left external jugular vein was aseptically exposed and cannulated with a 7F single-lumen central venous catheter (Arrow International Inc.) for chemical infusions. Normal saline with 5\% glucose was given intravenously via the line in the piglet's marginal vein of the pinna by dripping at an hourly rate of $5 \mathrm{~mL} / \mathrm{kg}$. The right common femoral artery was exposed and cannulated with a 7F two-lumen central venous catheter (Arrow International, Inc.), and the catheter tip was advanced to lie in the proximal abdominal aorta for blood pressure measurements and blood sampling. We used a multiparameter physiological monitor (Hewlett Packard, 78399A) to monitor blood pressure, heart beats, and electrocardiography continuously. In addition, we inserted a 7.5F Swan-Ganz continuous cardiac output, mixed venous oxygen saturation monitoring $\left(\mathrm{CCO} / \mathrm{SvO}_{2}\right)$ catheter (Edwards Lifesciences, $\left.744 \mathrm{H}\right)$ via the right common femoral vein into the pulmonary artery and used a Vigilance monitor (Edwards Lifesciences) to monitor the pulmonary artery pressure (PAP), pulmonary capillary wedge pressure (PCWP), and central venous pressure (CVP) (Figure 2). The cardiac output $(\mathrm{CO})$ was continuously measured using the thermodilution principle. The body surface area, cardiac index (CI), systemic vascular resistance index (SVRI), pulmonary vascular resistance index (PVRI), left-ventricular stroke work index (LVSWI), and rightventricular stroke work index (RVSWI) were calculated for comparison. 


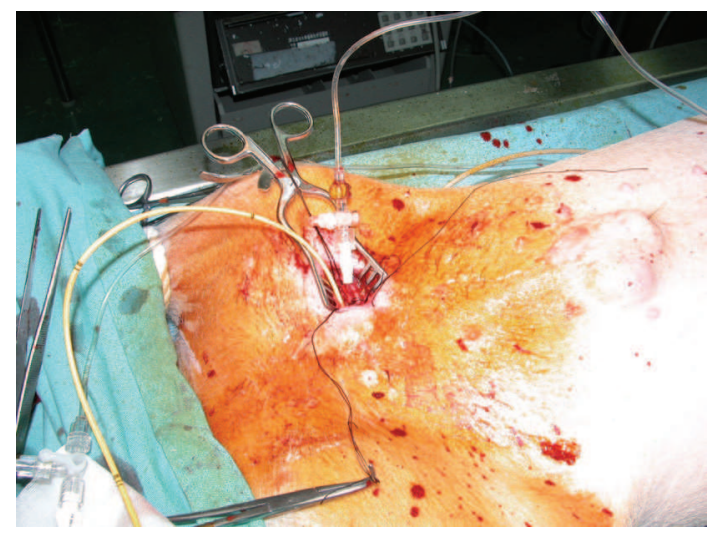

Fig. 2. Implantation of Swan-Ganz catheters during experiment.

\subsection{Protocol for chemical infusion and data collection}

After a stabilization period of approximately $20 \mathrm{~min}$, we sampled blood for ABG, complete blood cell counts (CBC), and biochemistry, and recorded the mean arterial blood pressure (MABP), HR, CVP, MPAP, PCWP, and CO as baseline values. We separated piglets into five experimental groups: (1) control, receiving normal saline (NS), (2) G, receiving glyphosate ([N-(phosphonomethyl) glycine], Sigma-Aldrich, St. Louis, USA) $360 \mathrm{mg} / \mathrm{mL}$ in sodium hydroxide $(\mathrm{NaOH})(\sim 2.13 \mathrm{M}, \sim \mathrm{pH} 5.7)$, (3) IPA, receiving IPA (CAS Number 75-31-0, Merck Schuchardt OHG, Hohenbrunn, Germany) $126 \mathrm{mg} / \mathrm{mL}$ in water ( 2.13 M, p pH 12.9), (4) IPAG group, receiving $N$-(phosphonomethyl) glycine, monoisopropylamine salt solution (Sigma-Aldrich) , $40 \mathrm{wt} \%$ ( 2.13 M, pH 5.0), and (5) POEA group, receiving alkoxylated fatty amine (Kudos SL-101C, CAS Number 61791-26-2, Zhang Jia Gang Kudos Chemical Co. Ltd.) $15 \%$ in water, final $\sim \mathrm{pH}$ 11.6. The concentration chosen for G, IPA, IPAG, and POEA were based on 40 wt \% IPAG solution and 15\% POEA.

In our preliminary study, we performed cardiographic examinations on piglets receiving different rates of IPAG infusions. We found that an infusion rate of $10 \mathrm{~mL} / \mathrm{h}$ IPAG ( 2.13 $\mathrm{M})$ could result in slow reduction in blood pressure, and sudden death with ventricular arrhythmia or reversible depression of left-ventricular function may occur after discontinuing infusion right after the MABP decreased to $50 \%$ of the initial value. At an infusion rate higher than $10 \mathrm{~mL} / \mathrm{h}$, most piglets died soon after the IPAG infusion. For other chemicals, no obvious reduction in MABP values was noted within one hour of infusion at the rate of $10 \mathrm{ml} / \mathrm{h}$. Therefore, we infused IPAG at $10 \mathrm{ml} / \mathrm{hr}$ and selected a $50 \%$ reduction in the MABP of the initial value $(50 \% \mathrm{MABP})$ as the endpoint. The surviving piglets were then observed for up to $2 \mathrm{~h}$ from the beginning of the IPAG infusion. The NS, G, IPA, and POEA were infused at a rate of $10 \mathrm{~mL} / \mathrm{h}$ for $1 \mathrm{~h}$ and then for another hour of observation. Temperature, HR, MABP, MPAP, CVP, PCWP, and CO values were recorded every 5 min. After the two hours of the experiments, the daily activities and urine amounts in the surviving piglets were observed and recorded for two days. Blood was sampled for ABG, $\mathrm{CBC}$, biochemistry and serum glyphosate during the experiment and at 24 and $48 \mathrm{~h}$ after the chemical infusion began. 


\subsection{Serum levels of glyphosate analyzed by high-performance liquid chromatography (HPLC)}

To explore the concentration change of glyphosate during infusion, serum concentrations of glyphosate were analyzed in the G and IPAG groups. We adopted HPLC method to measure serum levels of glyphosate, using a PerkinElmer LC 295 with a variable wavelength ultraviolet detector operated at a wavelength of $195 \mathrm{~nm}$, and an anion-exchange column $(4.6 \mathrm{~mm} \times 250 \mathrm{~mm}$, Partisil $10 \mu \mathrm{M}$ SAX). Blood samples were centrifuged and the supernatants were then diluted and filtered through $0.2 \mu \mathrm{m}$ nylon membranes before the analysis. The samples were dissolved in a mobile phase consisting of $0.05 \mathrm{M}$ potassium dihydrogen phosphate $\left(\mathrm{KH}_{2} \mathrm{PO}_{4}\right)$ in 60:40 $\mathrm{KH}_{2} \mathrm{PO}_{4}$ : water, adjusted to $\mathrm{pH} 1.9$ with phosphoric acid $\left(\mathrm{H}_{3} \mathrm{PO}_{4}\right)$. The flow rate of the mobile phase was $1.0 \mathrm{ml} / \mathrm{min}$. A sample of 20 $\mu \mathrm{L}$ was used for each injection. The detection limit is $1 \mathrm{ppm}$ and the coefficient of variation was $<10 \%$.

\subsection{Statistical analysis}

All numerical values are presented as means \pm SEM. We used the general linear model (GLM) for repeated measures in comparing hemodynamic data, paired $t$ test in comparing ABG data, and analysis of variance in comparing other data. One-compartment model intravenous infusion equations (Brewster et al., 1991; Bauer LA, 2006) were used for calculating the elimination rate constant $\left(\mathrm{K}_{\mathrm{e}}\right)$, the half-life $\left(\mathrm{t}_{1 / 2}\right)$, and the volume distribution (V), which are:

$$
\begin{gathered}
t_{\frac{1}{2}}=\frac{0.693}{K_{e}} \\
K_{e}=-\frac{\ln C_{1}-\ln C_{2}}{t_{1}-t_{2}} \\
V=\frac{K_{0}\left(1-e^{-K_{e} t^{\prime}}\right)}{K_{e}\left[C_{\max }-\left(C_{\text {predose }} e^{-K_{e} t^{\prime}}\right)\right]}
\end{gathered}
$$

Where $t_{1} / C_{1}$ is the first time/concentration pair, $t_{2} / C_{2}$ is the second time/concentration pair, $K_{0}$ is the infusion rate, $t^{\prime}=$ infusion time, $C_{\max }$ is the maximum concentration at the end of infusion, and $C_{\text {predose }}$ is the predose concentration. All statistical tests were performed at the two-tailed significance level of 0.05 .

\subsection{Results}

Table 4 shows the average infused dose of IPAG, G, IPA, and POEA in each group was $159.80 \pm 15.79 \mathrm{mg} / \mathrm{kg}$ (piglet weight), $238.47 \pm 17.49 \mathrm{mg} / \mathrm{kg}, 75.24 \pm 4.51 \mathrm{mg} / \mathrm{kg}$, and 0.0944 $\pm 0.00546 \mathrm{ml} / \mathrm{kg}$. Both POEA and IPAG finally caused a fatality rate of $66.7 \%(4 / 6)$.

At the beginning of the experiment, we compared the MABP among all the groups. IPAG infusion reduced MABP from $89.17 \pm 4.10$ to $47.50 \pm 6.02 \mathrm{mmHg}$, which reached $50 \%$ MABP at around $30.50 \pm 1.67 \mathrm{~min}$ after the infusion began, and $50 \%(3 / 6)$ piglets died soon after that time point with the presentation of ventricular arrhythmia. After discontinuation, the MABP increased to the initial level in the piglets surviving after infusion. The IPA 


\begin{tabular}{|c|c|c|c|c|c|}
\hline Parameters & $\begin{array}{l}\text { Control } \\
(N=3)\end{array}$ & $\begin{array}{l}\text { Glyphosate }^{\mathrm{a}} \\
(\mathbf{N}=6)\end{array}$ & $\begin{array}{c}\text { Isopropylam } \\
\text { ine }^{\mathrm{a}} \\
(\mathrm{N}=6)\end{array}$ & $\begin{array}{c}\text { Isopropylamine } \\
\text { salt of glyphosate } \\
(\mathbf{N}=6)\end{array}$ & $\begin{array}{c}\text { Polyoxyethylene- } \\
\text {-amine }^{\mathrm{a}}(\mathrm{POEA}) \\
(\mathrm{N}=6)\end{array}$ \\
\hline \multicolumn{6}{|l|}{ Body weight (kg) } \\
\hline Mean \pm SEM & $15.57 \pm 1.96$ & $15.47 \pm 1.02$ & $17.08 \pm 1.14$ & $16.43 \pm 1.43$ & $16.17 \pm 0.96$ \\
\hline \multicolumn{6}{|l|}{ Body height (cm) } \\
\hline Mean \pm SEM & $82.03 \pm 4.08$ & $81.07 \pm 1.59$ & $82.17 \pm 0.40$ & $79.40 \pm 1.64$ & $80.92 \pm 1.18$ \\
\hline \multicolumn{6}{|l|}{$\begin{array}{l}\text { Body surface } \\
\text { area }\left(\mathrm{m}^{2}\right)\end{array}$} \\
\hline Mean \pm SEM & $\begin{array}{c}0.563 \pm \\
0.052\end{array}$ & $\begin{array}{c}0.558 \pm \\
0.023\end{array}$ & $0.585 \pm 0.018$ & $0.565 \pm 0.028$ & $0.567 \pm 0.021$ \\
\hline $\begin{array}{l}\text { Administered } \\
\text { doses (mg/kg or } \\
\text { mL/kg piglet } \\
\text { weight) }\end{array}$ & & $\begin{array}{c}238.47 \pm \\
17.49 \\
\mathrm{mg} / \mathrm{kg}\end{array}$ & $\begin{array}{c}75.24 \pm 4.51 \\
\mathrm{mg} / \mathrm{kg}\end{array}$ & $\begin{array}{c}159.80 \pm 15.79 \\
\mathrm{mg} / \mathrm{kg}\end{array}$ & $\begin{array}{c}0.09 \pm 0.01 \\
\mathrm{ml} / \mathrm{kg}\end{array}$ \\
\hline \multicolumn{6}{|l|}{ Survival rate $(\%)$} \\
\hline $\begin{array}{c}\text { No. } \\
\text { surviving/total } \\
{[\text { no. }(\%)]}\end{array}$ & $\begin{array}{c}6 / 6 \\
(100.00 \%)\end{array}$ & $\begin{array}{c}6 / 6 \\
(100.00 \%)\end{array}$ & $\begin{array}{c}6 / 6 \\
(100.00 \%)\end{array}$ & $2 / 6(33.33 \%)^{*}$ & $2 / 6(33.33 \%)^{*}$ \\
\hline \multicolumn{6}{|l|}{$\begin{array}{l}\text { Urine amount on } \\
\text { postoperative } \\
\text { day } 1(\mathrm{~mL})\end{array}$} \\
\hline Mean \pm SEM & $\begin{array}{c}550.00 \pm \\
180.28\end{array}$ & $\begin{array}{c}345.00 \pm \\
91.60\end{array}$ & $\begin{array}{c}363.33 \pm \\
40.79\end{array}$ & $140.00 \pm 89.14^{\mathrm{b}}$ & $191.67 \pm 121.39 b$ \\
\hline \multicolumn{6}{|l|}{$\begin{array}{l}\text { Urine amount on } \\
\text { postoperative } \\
\text { day } 2(\mathrm{~mL})\end{array}$} \\
\hline Mean \pm SEM & $\begin{array}{c}533.33 \pm \\
169.15\end{array}$ & $\begin{array}{c}545.00 \pm \\
64.43\end{array}$ & $\begin{array}{c}451.67 \pm \\
32.09\end{array}$ & $160.00 \pm 101.32^{\mathrm{b}}$ & $208.33 \pm 135.66^{b}$ \\
\hline
\end{tabular}

SEM, standard error of the mean.

aThe administered concentration for glyphosate, isopropylamine, IPAG, and polyoxyethyleneamine were calculated based on $40 \mathrm{wt} \%$ IPAG solution and $15 \%$ polyoxyethyleneamine, equal to $0.296 \mathrm{~g} / \mathrm{g}$ (isopropylamine salt of solution), $0.104 \mathrm{~g} / \mathrm{g}, 0.40 \mathrm{~g} / \mathrm{g}$, and $0.15 \mathrm{~mL} / \mathrm{mL}$ ethoxylated tallowamine in water.

bOnly two surviving piglets were counted.

* $\mathrm{p}<0.01$ by Pearson's $\chi^{2}$ test.

Data from Lee et al, 2009.

Table 4. Values of body weight, body height, body surface area, survival rate, average survival time, and urine amount at postoperative days 1 and 2 in the five groups. 
infusion led a marked increase in MABP. In all the other experimental groups, no significant changes in the MABP during the chemical infusion were observed. The average infused dose of IPAG, G, IPA, and POEA was $159.80 \pm 15.79 \mathrm{mg} / \mathrm{kg}$ (piglet weight), $238.47 \pm 17.49$ $\mathrm{mg} / \mathrm{kg}, 75.24 \pm 4.51 \mathrm{mg} / \mathrm{kg}$, and $0.0944 \pm 0.00546 \mathrm{ml} / \mathrm{kg}$. Although HR decreased gradually in the IPAG and POEA groups (10-30 min in the IPAG group and 35-100 min in the POEA group, $p<0.05)$, there was no significant difference in HR between these groups.

Compared to NS and G, IPAG and POEA had markedly decreased the CI after the initiation of infusion. Contrarily, the PCWP increased markedly in the IPAG and POEA groups. No significant changes in the CI or PCWP were noted in the G or IPA group. IPAG also increased the CVP and MPAP, but only a temporary increase in MPAP was noted.

The LVSWI, RVSWI, SVRI, PVRI calculated from MAP, PCWP, the stroke volume index (SVI), PAP, and CVP, were compared among the groups. IPAG infusion significantly reduced the LVSWI values, which subsequently stabilized after the discontinuation of the treatment. POEA also gradually reduced LVSWI during and after its infusion. These two chemicals also increased the values of PVRI, which were significantly different from those in the G group $(p<0.05)$. Whereas IPAG had no effect on the RVSWI, it increased the SVRI values after the discontinuation of infusion. POEA had no effect on the RVSWI or SVRI. Although IPA only transiently increased the RVSWI values during the infusion period (15$60 \mathrm{~min}$ ), it significantly increased the PVRI values, which were higher than those of the G group. In contrast, G had no effect on the LVSWI, RVSWI, SVRI, or PVRI.

Table 5 shows the analysis of blood gas during the experiment. The initial mean $\mathrm{pH}$ was 7.45-7.51 in all experimental groups. The inhalation of oxygen during anesthesia caused elevated arterial blood $\mathrm{P}_{\mathrm{O} 2}$ initially, ranging from 186.50 to $210.17 \mathrm{mmHg}$, and the $\mathrm{P}_{\mathrm{CO} 2}$ were maintained around $35.83-41.33 \mathrm{mmHg}$. The initial lactate and base excess (BE) concentrations were similar across the groups. No significant changes in the arterial blood $\mathrm{pH}, \mathrm{P}_{\mathrm{O} 2}, \mathrm{P}_{\mathrm{CO} 2}$, lactate, or $\mathrm{BE}$ occurred in the control group. POEA caused a reduction in the $\mathrm{pH}$ at the end of experiment $(p<0.01)$, accompanied by a gradual increase in lactate $(p<$ 0.01 ) and a reduction in $\mathrm{BE}$, which is compatible with the process of metabolic acidosis. Similar results were observed in the IPAG group, which also had an increase in lactate and a reduction in $\mathrm{BE}$ during and after infusion $(p<0.01)$, with a slight reduction in the $\mathrm{P}_{\mathrm{CO} 2}$ value during infusion. The $\mathrm{G}$ group had a reduction in $\mathrm{pH}$ and $\mathrm{BE}$, with no changes in the other parameters during or after infusion. Unlike POEA, G, and IPAG, IPA caused a gradual increase in the BE.

A glyphosate standard and serum glyphosate concentrations were analyzed by HPLC as described in the Methods. Under the conditions employed in our study, glyphosate had a retention time of 10-11 min. The blood samples at different time points had retention time similar to parent glyphosate. The dose used in the $\mathrm{G}$ group produced an average glyphosate concentration of $166.54 \pm 63.96,236.47 \pm 83.15$, and $180.27 \pm 33.19 \mathrm{ppm}$ at 30,45 , and $60 \mathrm{~min}$ after its administration, and the chemical was barely detectable after nearly $48 \mathrm{~h}$; while in the IPAG group, an average glyphosate concentration of $731.28 \pm 151.38 \mathrm{ppm}$ was detected at 50\% MABP (around $30.5 \mathrm{~min}$, averagely), and it could be detected with an average of $148.74 \pm 73.36 \mathrm{ppm}$ after nearly $48 \mathrm{~h}$. The glyphosate concentration detected in IPAG infusion was four times higher than that in $G$ infusion at $\sim 30 \mathrm{~min}$. We observe no plateau 


\begin{tabular}{|c|c|c|c|c|c|}
\hline Chemicals & $\mathrm{pH}$ & $\begin{array}{c}\mathrm{P}_{\mathrm{O} 2} \\
(\mathrm{mmHg})\end{array}$ & $\begin{array}{c}\mathrm{P}_{\mathrm{CO} 2} \\
(\mathrm{mmHg})\end{array}$ & Lactate & $\begin{array}{c}\mathrm{BE} \\
(\mathrm{mEq} / \mathrm{L}) \\
\end{array}$ \\
\hline \multicolumn{6}{|l|}{$\begin{array}{l}\text { Control (normal } \\
\text { saline) }\end{array}$} \\
\hline Initial (mean $\pm S E M)$ & $\begin{array}{c}7.47 \pm \\
0.01\end{array}$ & $\begin{array}{c}205.33 \pm \\
1.21\end{array}$ & $\begin{array}{c}41.33 \pm \\
3.71\end{array}$ & $\begin{array}{c}1.47 \pm \\
0.37\end{array}$ & $\begin{array}{c}6.27 \pm \\
1.69\end{array}$ \\
\hline $60 \min ($ mean $\pm S E M)$ & $\begin{array}{c}7.47 \pm \\
0.02\end{array}$ & $\begin{array}{c}198.67 \pm \\
7.86\end{array}$ & $\begin{array}{c}41.33 \pm \\
4.71\end{array}$ & $\begin{array}{c}1.43 \pm \\
0.09\end{array}$ & $\begin{array}{c}6.47 \pm \\
2.32\end{array}$ \\
\hline Final (mean \pm SEM) & $\begin{array}{c}7.46 \pm \\
0.02\end{array}$ & $\begin{array}{l}227.00 \pm \\
35.64\end{array}$ & $\begin{array}{l}40.67 \pm \\
3.93\end{array}$ & $\begin{array}{c}1.23 \pm \\
0.07\end{array}$ & $\begin{array}{l}5.27 \pm \\
1.68\end{array}$ \\
\hline \multicolumn{6}{|l|}{$\begin{array}{l}\text { Glyphosate (NaOH } \\
\text { base) }\end{array}$} \\
\hline Initial (mean \pm SEM) & $\begin{array}{l}7.51 \pm \\
0.02\end{array}$ & $\begin{array}{c}210.17 \pm \\
6.96\end{array}$ & $\begin{array}{l}35.83 \pm \\
2.86\end{array}$ & $\begin{array}{c}1.37 \pm \\
0.12\end{array}$ & $\begin{array}{l}5.55 \pm \\
1.43\end{array}$ \\
\hline $60 \min ($ mean \pm SEM $)$ & $\begin{array}{l}7.45 \pm \\
0.02^{* *}\end{array}$ & $\begin{array}{c}193.83 \pm \\
6.46\end{array}$ & $\begin{array}{l}37.83 \pm \\
3.43\end{array}$ & $\begin{array}{c}1.55 \pm \\
0.17\end{array}$ & $\begin{array}{l}2.03 \pm \\
1.00^{* *}\end{array}$ \\
\hline Final (mean \pm SEM) & $\begin{array}{c}7.47 \pm \\
0.02^{*}\end{array}$ & $\begin{array}{c}193.83 \pm \\
9.89\end{array}$ & $\begin{array}{c}37.10 \pm \\
2.58\end{array}$ & $\begin{array}{c}1.63 \pm \\
0.25\end{array}$ & $\begin{array}{l}3.37 \pm \\
1.59^{*}\end{array}$ \\
\hline \multicolumn{6}{|l|}{ Isopropylamine } \\
\hline Initial (mean $\pm S E M)$ & $\begin{array}{c}7.45 \pm \\
0.02\end{array}$ & $\begin{array}{c}193.00 \pm \\
11.72\end{array}$ & $\begin{array}{c}39.67 \pm \\
2.35\end{array}$ & $\begin{array}{c}1.83 \pm \\
0.39\end{array}$ & $\begin{array}{c}4.17 \pm \\
2.24\end{array}$ \\
\hline 60 min $($ mean $\pm S E M)$ & $\begin{array}{l}7.46 \pm \\
0.03\end{array}$ & $\begin{array}{c}179.83 \pm \\
8.75\end{array}$ & $\begin{array}{c}43.33 \pm \\
2.32\end{array}$ & $\begin{array}{l}1.81 \pm \\
0.55\end{array}$ & $\begin{array}{l}7.43 \pm \\
2.46^{*}\end{array}$ \\
\hline Final (mean \pm SEM) & $\begin{array}{l}7.48 \pm \\
0.03\end{array}$ & $\begin{array}{c}201.17 \pm \\
25.9\end{array}$ & $\begin{array}{c}43.17 \pm \\
2.27\end{array}$ & $\begin{array}{c}1.43 \pm \\
0.16\end{array}$ & $\begin{array}{l}8.82 \pm \\
2.24^{* *}\end{array}$ \\
\hline \multicolumn{6}{|l|}{ Polyoxyethyleneamine } \\
\hline Initial $($ mean $\pm S E M)$ & $\begin{array}{l}7.48 \pm \\
0.03\end{array}$ & $\begin{array}{c}196.67 \pm \\
10.55\end{array}$ & $\begin{array}{c}38.83 \pm \\
3.99\end{array}$ & $\begin{array}{c}1.67 \pm \\
0.26\end{array}$ & $\begin{array}{l}4.72 \pm \\
1.00\end{array}$ \\
\hline $60 \min ($ mean $\pm S E M)$ & $\begin{array}{c}7.46 \pm \\
0.04\end{array}$ & $\begin{array}{c}196.17 \pm \\
12.86\end{array}$ & $\begin{array}{c}31.17 \pm \\
3.64^{*}\end{array}$ & $\begin{array}{l}3.97 \pm \\
0.62^{* *}\end{array}$ & $\begin{array}{c}-1.42 \pm \\
1.45^{*}\end{array}$ \\
\hline Final (mean \pm SEM) & $\begin{array}{l}7.23 \pm \\
0.06^{* *}\end{array}$ & $\begin{array}{c}167.83 \pm \\
25.09\end{array}$ & $\begin{array}{c}38.83 \pm \\
3.82\end{array}$ & $\begin{array}{l}7.58 \pm \\
1.04^{\star *}\end{array}$ & $\begin{array}{c}-9.41 \pm \\
2.62^{* *}\end{array}$ \\
\hline \multicolumn{6}{|l|}{$\begin{array}{l}\text { Isopropylamine salt of } \\
\text { glyphosate }\end{array}$} \\
\hline Initial (mean \pm SEM) & $\begin{array}{c}7.49 \pm \\
0.01\end{array}$ & $\begin{array}{c}186.50 \pm \\
12.03\end{array}$ & $\begin{array}{l}40.67 \pm \\
1.96\end{array}$ & $\begin{array}{c}1.33 \pm \\
0.12\end{array}$ & $\begin{array}{c}7.65 \pm \\
1.76\end{array}$ \\
\hline $\begin{array}{c}50 \% \text { of MABP }(\text { mean } \pm \\
\text { SEM) }\end{array}$ & $\begin{array}{c}7.50 \pm \\
0.02\end{array}$ & $\begin{array}{c}189.67 \pm \\
10.50\end{array}$ & $\begin{array}{l}30.83 \pm \\
2.06^{* *}\end{array}$ & $\begin{array}{l}2.12 \pm \\
0.20^{\star *}\end{array}$ & $\begin{array}{l}0.90 \pm \\
1.08^{* *}\end{array}$ \\
\hline Final (mean \pm SEM) & $\begin{array}{l}7.42 \pm \\
0.05\end{array}$ & $\begin{array}{c}124.50 \pm \\
30.68\end{array}$ & $\begin{array}{c}34.01 \pm \\
5.51 \\
\end{array}$ & $\begin{array}{l}3.78 \pm \\
0.67^{\star *}\end{array}$ & $\begin{array}{c}-3.01 \pm \\
2.59^{* *}\end{array}$ \\
\hline
\end{tabular}

SEM, standard error of the mean.

${ }^{*} \mathrm{p}<0.05$ vs. Initial; ${ }^{* *} \mathrm{p}<0.01$ vs. Initial.

Data from Lee et al., 2009.

Table 5. Arterial blood gas analysis at $60 \mathrm{~min}$ after control (normal saline), glyphosate, isopropylamine, or polyoxyethyleneamine injection and at $50 \%$ of the mean arterial blood pressure (MABP) after treatment with isopropylamine salt of glyphosate. 
concentration for each piglet and therefore used the average concentrations for calculating pharmacokinetic parameters. For $G$ infusion, the $t_{1 / 2}$ of glyphosate was $1.52 \mathrm{~h}$, the $\mathrm{K}_{\mathrm{e}}$ was $0.46 \mathrm{~h}^{-1}$, and the V was 16.05 liter (L); for IPAG infusion, they were $1.46 \mathrm{~h}, 0.47 \mathrm{~h}^{-1}$, and 3.92 L, respectively.

\subsection{Conclusion and discussion 5.7.1 Infusion of IPA}

In our study, the persistent elevated MABP and PVRI and the reversible RVSWI during IPA infusion suggest an inotropic effect of IPA. The lower dose used in our study $(1.2-1.4 \mathrm{mg} / \mathrm{kg}$ per min vs. $2.5 \mathrm{mg} / \mathrm{kg}$ per min) may account for the differences observed between our and the other study (Privitera et al., 1982).

\subsubsection{Infusion of IPAG}

In contrast to G and IPA, POEA and IPAG infusions introduced high death rates. IPAG infusion lowered cardiac contractility and the MABP, accompanied by increases in the MPAP and vascular resistance, which caused heart failure. A $66.7 \%$ fatality rate and blood lactate formation with lowered BE values were noted following its infusion with $\sim 50 \%$ of the dose in the concentration similar to other chemicals. No pulmonary rales were detected by auscultation during the experiments, and no hypoxemia, severe acidosis or alkalosis, or obvious $\mathrm{pH}$ changes that could result in changes in pulmonary vascular resistance or cardiac dysfunction were noted during the experiments. Uncoupling mitochondrial oxidative phosphorylation and reduced the respiratory control ratios of mitochondria have been reported as the possible toxic mechanism of glyphosate, IPAG or GlySH (Bababunmi et al., 1979; Olorunsogo et al., 1979a; Peixoto, 2005), which may be one of the reasons used for the explanation of lactate formation and acidosis; nevertheless, back to the level of more complex organisms with effective buffering capacities, we could not see severe acidosis with huge $\mathrm{pH}$ changes that could sufficiently lead to hemodynamic dysfunction. Therefore, the changes in the cardiovascular parameters in our study imply direct depressive cardiovascular and vasoactive effects exerted by IPAG.

\subsubsection{Infusion of POEA}

In our study, although POEA did not significantly affect MABP during the infusion period, it progressively depressed left-side ventricular function (decreased the CI and LVSWI and increased the PCWP and CVP), and increased pulmonary vasoconstriction effects (increased the MPAP and PVRI) during and after its infusion, leading to metabolic acidosis with the accumulation of lactate noted at $60 \mathrm{~min}$ and at the end of the experiment. In the POEA group, $66.7 \%(4 / 6)$ of the piglets died between 1 and $3 \mathrm{~h}$ after the discontinuation of this chemical. In a dog study, Tai et al. (1990) found that surfactant infusion decreased the MABP, CO, and LVSWI, and Koyama et al. (1994) reported similar effects in rats, when the surfactant polyoxyethylene alkylether produced negative chronotropic and inotropic responses. Reviewing the experimental records, we found that the increases in anal temperatures in the five groups, under the control of warm blanket, was no more than 1.4 ${ }^{\circ} \mathrm{C}$, and the blood glucose levels, under the support of intravenous glucose/saline fluids, were kept around 100-200 mg/dL. The biochemistry data checked during one hour of 
chemical infusions showed no evidence of acute change in renal or liver function. The mild increase of lactate in the IPAG group might be induced by circulatory collapse or uncoupled oxidative phosphorylation. Because we found no report of uncoupled oxidative phosphorylation effects, the increase in lactate in the POEA group was most likely due to circulatory collapse which could worsen acidosis and lead to death. It is commonly assumed that acute acidosis could have adverse effects on hemodynamics. Therefore, it can be speculated that the deaths of our experimental animals from uncorrected metabolic acidosis was attributable to the infusion of POEA.

\subsubsection{Infusion of glyphosate in $\mathrm{NaOH}$ base}

The infusion of glyphosate in $\mathrm{NaOH}$ base had a reduction in $\mathrm{pH}$ and $\mathrm{BE}$, with no significant hemodynamic changes during or after infusion.

\subsubsection{Serum concentration of glyphosate during the infusion of glyphosate in $\mathrm{NaOH}$ and IPA base}

According to the metabolic and pharmacokinetic studies, the vast majority of the body burden after the administration of glyphosate is unchanged parent glyphosate and no toxic metabolites are produced (Williams et al., 2000; Brewster et al., 1991). Human data on the kinetics of glyphosate are rare. The analysis of plasma concentration-time profiles in a prospective study of acute GlySH self-poisoning in adults suggested that the elimination of glyphosate is the first-order elimination and the best-fit apparent elimination $t_{1 / 2}$ of glyphosate is $3.1 \mathrm{~h}$ with a fairly narrow 95\% C.I. of 2.7-3.6 h (Roberts et al., 2010). However, another study in rat showed after single $100 \mathrm{mg} \mathrm{kg}^{-1}$ intravenous (i.v.) and $400 \mathrm{mg} \mathrm{kg}^{-1}$ oral doses administration, plasma concentration-time curves were best described by a twocompartment open model; the elimination $t_{1 / 2}$ of $\alpha$ and $\beta$ phase (distribution and elimination terminal phase) for glyphosate from plasma were $0.345 \mathrm{~h}$ and $9.99 \mathrm{~h}$ after i.v. and $4.17 \mathrm{~h}$ and $14.38 \mathrm{~h}$ after oral administration (Anadón et al., 2009). In our study, at the same infused concentration and infusion rate, the calculated $t_{1 / 2}$ and $K_{e}$ values for glyphoaste in the $\mathrm{G}$ and IPAG infusion groups were relatively close (for $\mathrm{G}$ infusion, $\mathrm{t}_{1 / 2} 1.52$ $\mathrm{h}, \mathrm{K}_{\mathrm{e}} 0.46 \mathrm{~h}^{-1}$; for IPAG infusion, $1.46 \mathrm{~h}, 0.47 \mathrm{~h}^{-1}$, respectively). Distribution, elimination, and metabolism data are very important for being extrapolated from experimental animals to humans; however, they may vary across different study design in different experimental animals. In our piglet study, the elimination of glyphosate in intravenous infusion is described by a one-compartment model with the first-order elimination, which is similar to the report of Robert et al. in GlySH poisoning in humans.

In addition, a higher concentration of glyphosate was detected in the IPAG group than in the $\mathrm{G}$ group at the approximate time point (731 ppm vs. $167 \mathrm{ppm}$ ). This phenomenon could be explained by the different dissociation ability of IPA and $\mathrm{NaOH}$ salts. Since IPA is a weak base and $\mathrm{NaOH}$ is a strong base, in the environment of $\sim \mathrm{pH} 7.4$ (blood), IPA salt would more easily dissociate than $\mathrm{NaOH}$ salt; thus, higher concentration of glyphosate in serum could be detected in the IPAG group. This might be one of the reasons that glyphosate in $\mathrm{NaOH}$ base with a $\mathrm{pH}$ of 5.7 had no obvious impact on hemodynamics during infusion, except for mild reductions in $\mathrm{pH}$ and $\mathrm{BE}$ values which were still within normal ranges. In 
contrast, glyphosate in the form of IPA salt produced more severe hemodynamic insults in our study.

\section{Summary}

GlySH has been commonly used in suicide attempt in Taiwan and other Asia countries. Case fatality rate ranged from 1.9 to $29.3 \%$ in Taiwan (Chen et al., 2009). The risk factors of fatality or severity of GlySH exposure identified are amount of exposure, hypovolemic shock, intractable shock, acute pulmonary edema, Acute Physiology and Chronic Health Evaluation II score, age, male gender, laryngeal injury with aspiration, abnormal chest Xray, calendar time, reason for exposure, atropine therapy, elapsed time, delayed presentation, number of involved organs, hyperkalemia, metabolic acidosis, tachycardia, elevated serum creatinine, and high plasma glyphosate concentrations on admission $(>734$ ug/mL) (Sawada et al., 1988; Tominack et al., 1991; Talbot et al., 1991; Hung et al., 1997; Lee et al., 2000; Lee et al., 2008; Chen et al., 2009; Roberts et al., 2010). All the patients who are reported to have ingested large amounts of GlySH should be carefully observed, especially for those who present with respiratory distress, unstable hemodynamics, and old age. In managing patients who have larger amount of GlySH ingestion, airway protection, early detection of pulmonary edema, and prevention of further pulmonary damage and renal damage appear to be of critical importance.

GlySH poisoning may induce severe cardiovascular symptoms in humans (Talbot et al., 1991; Lin et al., 1999). Animal and cell studies have also shown that GlySH are more toxic than POEA or glyphosate itself (Tai et al., 1990; Martinez and Brown, 1991; Richard et al., 2005; Peixoto, 2005; Marc et al., 2002), and therefore synergistic effects between the components of GlySH have been proposed (Peixoto, 2005; Marc et al., 2002). In the second study, we demonstrated that the negative cardiovascular effects seen in GlySH poisoning could be attributable to the surfactant POEA, IPAG, or both. Glyphosate in $\mathrm{NaOH}$ base or IPA alone had no similar cardiovascular effects. Here, we first demonstrated that IPAG has effects similar to POEA and provide further insight into the cardiovascular effects of different salts of glyphosate and the adjuvants used in GlySH on experimental animals under the circumstance of chemical infusion. Further studies that clarify more precisely the mechanisms of the synergistic effect of glyphosate and IPA are required.

In the evaluation of the toxicity of pesticides, the current practice is to evaluate the active ingredients. The current study shows that the adjuvant can be toxic. Therefore, the toxicity pattern related to the combination of active ingredients with adjuvants should be taken into consideration when evaluating the toxicity threshold of mixtures of pesticides. Furthermore, efforts should be taken to search for the safest formula in the development of commercially available pesticide products.

\section{References}

Adam A.; Marzuki A.; Abdul R.H.; Abdul A.M. (1997). The oral and intratracheal toxicities of ROUNDUP and its components to rats. Veterinary $\mathcal{E}$ Human Toxicology, Vol. 39, No. 3, pp. 147-151. ISSN: 0145-6296. 
Anadón A.; Martínez-Larrañaga M.R.; Martínez M.A.; Castellano V.J.; Martínez M.; Martin M.T.; Nozal M.J. \& Bernal J.L. (2009). Toxicokinetics of glyphosate and its metabolite aminomethyl phosphonic acid in rats. Toxicology Letters, Vol. 190, No. 1, pp. 91-95, ISSN: 0378-4274.

Bababunmi E.A.; Olorunsogo O.O. \& Bassir O. (1979). The uncoupling effect of N(phosphonomethyl) glycine on isolated rat liver mitochondria. Biochemical Pharmacology, Vol. 28, No. 6, pp. 925-927. ISSN: 0006-2952.

Bauer L.A. (2006) Clinical pharmacokinetic equations and calculations, In: Clinical pharmacokinetics Handbook, Brown M. \& Edmonson K. (Ed.), pp. 19-32, McGraw-Hill Medical, ISBN: 007142542X.

Bingham E.; Cohrssen B. \& Powell C.H. (2001). Patty's Toxicology, Vo. 4, $5^{\text {th }}$ ed., John Wiley \& Sons, Inc., ISBN: 047131935X, New York, NY 2001.

Bradberry S.M.; Proudfoot A.T. \& Vale J.A. (2004). Glyphosate poisoning. Toxicological Reviews, Vol. 23, No. 3, pp. 159-167. ISSN: 1176-2551.

Brewster D.W.; Warren J. \& Hopkins W.E. (1991). Metabolism of glyphosate in SpragueDawley rats: tissue distribution, identification, and quantitation of glyphosatederived materials following a single oral dose. Fundamental and Applied Toxicology, Vol. 17, No. 1, pp. 43-51, ISSN: 0272-0590.

Chen Y.-J.; Wu M.-L.; Deng J.-F. \& Yang C.-C. (2009). The epidemiology of glyphosatesurfactant herbicide poisoning in Taiwan, 1986-2007: a poison center study. Clinical Toxicology (Phila), Vol. 47, No. 7, pp. 70-677, ISSN: 1556-3650.

EPA US. (1993). Glyphosate, In: Reregistration Eligibility Decision Document, Special Review and Reregistration Division, Office of Pesticide Programs, Washington, D.C.

Harbison R.D. (1998). Hamilton and Hardy's Industrial Toxicology, Mosby-Year Books, ISBN: 0815141815, St. Louis, MO.

Hietanen E.; Linnainmaa K. \& Vainio H. (1983). Effects of phenoxyherbicides and glyphosate on the hepatic and intestinal biotransformation activities in the rat. Acta Pharmacologica et Toxicologica (Copenh), Vol. 53, No. 2, pp. 103-112. ISSN: 00016683.

Hung D.-Z.; Deng J.-F. \& Wu T.-C. (1997). Laryngeal survey in glyphosate intoxication: a pathophysiological investigation. Human E Experimental Toxicology, Vol. 16, No. 10, pp. 596-599. ISSN: 0960-3271.

Ishizaki T.; Privitera P.J.; Walle T. \& Gaffney T.E. (1974). Cardiovascular actions of a new metabolite of propranolol: isopropylamine. The Journal of Pharmacology and Experimental Therapeutics, Vol. 189, No. 3, pp. 626-632. ISSN: 0022-3565.

Kawamura K.; Nobuhara H.; Tsuda K.; Tanaka A.; Matsubara Y. \& Yamauchi N. (1987). Two cases of glyphosate (Roundup) poisoning. Pharmaceuticals Monthly (Japanese), Vol. 29, pp.163-166, ISSN: 0016-5980.

Koyama K.; Goto K. \& Yamashita M. (1994). Circulatory failure caused by a fungicide containing iminoctadine and a surfactant: a pharmacological analysis in rats. Toxicology and Applied Pharmacology, Vol. 126, No. 2, pp.197-201, ISSN: 0041008X. 
Lee C.-H.; Shih C.-P.; Hsu K.-H.; Hung D.-Z. \& Lin C.-C. (2008). The early prognostic factors of glyphosate-surfactant intoxication. The American Journal of Emergency Medicine, Vol. 26, No. 3, pp. 75-281. ISSN: 0735-6757.

Lee H.-L.; Chen K.-W.; Chi C.-H.; Huang J.-J. \& Tsai L.-M. (2000). Clinical presentations and prognostic factors of a glyphosate-surfactant herbicide intoxication: a review of 131 cases. Academic Emergency Medicine, Vol. 7, No. 8, pp. 906-910. ISSN: 1069-6563.

Lee H.-L.; Kan C.-D.; Tsai C.-L.; Liou M.-J. \& Guo H.-R. (2009). Comparative effects of the formulation of glyphosate-surfactant herbicides on hemodynamics in swine. Clinical Toxicology (Phila), Vol. 47, No. 7, pp. 651-658. ISSN: 1556-3650.

Lin C.-M.; Lai C.-P.; Fang T.-C. \& Lin C.-L. (1999). Cardiogenic shock in a patient with glyphosate-surfactant poisoning. Journal of the Formosan Medical Association, Vol. 98, No. 10, pp. 698-700. ISSN: 0929-6646.

Marc J.; Mulner-Lorillon O.; Boulben S.; Hureau D.; Durand G. \& Bellé R. (2002). Pesticide Roundup provokes cell division dysfunction at the level of CDK1/cyclin B activation. Chemical Research in Toxicology, Vol. 15, No. 3, pp. 326-331. ISSN: 0893$228 X$.

Martinez T.T. \& Brown K. (1991). Oral and pulmonary toxicology of the surfactant used in roundup herbicide. Proceedings of the Western Pharmacology Society, Vol. 34, pp.43-46. ISSN: 0083-8969.

Martinez T.T.; Long W.C. \& Hiller R. (1990). Comparison of the toxicology of the herbicide roundup by oral and pulmonary routes of exposure. Proceedings of the Western Pharmacology Society, Vol. 33, pp. 193-197. ISSN: 0083-8969.

Menkes D.B.; Temple W.A. \& Edwards I.R. (1991). Intentional self-poisoning with glyphosate-containing herbicides. Human E Experimental Toxicology, Vol. 10, No. 2, pp. 103-107. ISSN: 0960-3271.

Müller M.M.; Rosenberg C.; Siltanen H. \& Wartiovaara T. (1981). Fate of glyphosate and its influence on nitrogen-cycling in two Finnish agriculture soils. Bulletin of Environmental Contamination and Toxicology, Vol. 27, No. 5, pp. 724-730. ISSN: 00074861.

NFPA. (1997). Fire Protection Guide to Hazardous Materials. National Fire Protection Association, Quincy, MA.

Olorunsogo O.O.; Bababunmi E.A. \& Bassir O. (1979a). Effect of glyphosate on rat liver mitochondria in vivo. Bulletin of Environmental Contamination and Toxicology, Vol. 22, N0. 3, pp. 357-364. ISSN: 0007-4861.

Olorunsogo O.O.; Bababunmi E.A. \& Bassir O. (1979b). Uncoupling of corn shoot mitochondria by N-(phosphonomethyl) glycine. FEBS Letters, Vol. 97, No. 2, pp. 279-282. ISSN: 0014-5793.

Olorunsogo O.O.; Bababunmi E.A. \& Bassir O. (1980). Interaction of N-(phosphonomethyl) glycine with some respiratory chain enzymes of isolated corn-shoot mitochondria. Archives of Environmental Contamination and Toxicology, Vol. 9, No. 1, pp. 109-114. ISSN: 0090-4341.

Olorunsogo O.O. (1982). Inhibition of energy-dependent transhydrogenase reaction by N(phosphonomethyl) glycine in isolated rat liver mitochondria. Toxicology Letters, Vol. 10, No. 1, pp. 91-95. ISSN: 0378-4274. 
Olorunsogo O.O. (1990). Modification of the transport of protons and Ca2+ ions across mitochondrial coupling membrane by $\mathrm{N}$-(phosphonomethyl) glycine. Toxicology, Vol. 61, No. 2, pp. 205-209. ISSN: 0300-483X.

Peixoto F. (2005). Comparative effects of the Roundup and glyphosate on mitochondrial oxidative phosphorylation. Chemosphere, Vol. 61, No. 8, pp. 1115-1122. ISSN: 00456535.

Privitera P.J.; Walle T. \& Gaffney T.E. (1982). Nicotinic-like effects and tissue disposition of isopropylamine. The Journal of Pharmacology and Experimental Therapeutics, Vol. 222, No. 1, pp. 116-121. ISSN: 0022-3565.

Richard S.; Moslemi S.; Sipahutar H.; Benachour N. \& Seralini G.E. (2005). Differential effects of glyphosate and roundup on human placental cells and aromatase. Environmental Health Perspectives, Vol. 113, No. 6, pp. 716-720. ISSN: 0091-6765.

Roberts D.M.; Buckley N.A.; Mohamed F.; Eddleston M.; Goldstein D.A.; Mehrsheikh A.; Bleeke M.S. \& Dawson A.H. (2010). A prospective observational study of the clinical toxicology of glyphosate-containing herbicides in adults with acute self-poisoning. Clinical Toxicology, Vol. 48, No. 2, pp. 129-136. ISSN: 1556-3650.

Sawada Y. \& Nagai Y. (1987). Roundup intoxication-its clinical status and participation with surface active agents. Journal of Clinical and Experimental Medicine (Igaku No Ayumi), Vol. 143, pp. 25-27. ISSN: 0039-2359.

Sawada Y.; Nagai Y.; Ueyama M. \& Yamamoto I. (1988). Probable toxicity of surface-active agent in commercial herbicide containing glyphosate. Lancet, Vol. 1, No. 8580, pp. 299. ISSN: 0140-6736.

Smith E.A. \& Oehme F.W. (1992). The biological activity of glyphosate to plants and animals: a literature review. Veterinary and Human Toxicology, Vol. 34, No. 6, pp. 531-543. ISSN: 0145-6296.

Stella J. \& Ryan M. (2004). Glyphosate herbicide formulation: a potentially lethal ingestion. Emergency Medicine Australasia, Vol. 16, No. 3, pp. 235-239. ISSN: 1742-6731.

Suh J.H.; Oh B.J. \& Roh H.K. (2007). Clinical outcomes after suicidal ingestion of glyphosate surfactant herbicide: severity of intoxication according to amount ingested. Clinical Toxicology (Phila), Vol. 45, No. 6, pp. 641, ISSN: 1556-3650.

Tai T.; Yamashita M. \& Wakimori H. (1990). Hemodynamic effects of Roundup, Glyphosate and Surfactant in dogs. Japanese Journal of Toxicology (Chudoku Kenkyu), Vol. 3, pp. 63-68. ISSN: 0914-3777.

Talbot A.R.; Shiaw M.-H.; Huang J.-S.; Yang S.-F.; Goo T.-S.; Wang S.-H.; Chen C.-L. \& Sanford T.R. (1991). Acute poisoning with a glyphosate-surfactant herbicide ('Roundup'): a review of 93 cases. Human E Experimental Toxicology, Vol. 10, No. 1, pp. 1-8. ISSN: 0960-3271.

Tominack R.L.; Yang G.-Y.; Tsai W.-J.; Chung H.-M. \& Deng J.-F. (1991). Taiwan National Poison Center survey of glyphosate--surfactant herbicide ingestions. Journal of Toxicology - Clinical Toxicology, Vol. 29, No. 1, pp. 91-109. ISSN: 0731-3810.

van der Hoek W. \& Konradsen F. (2006). Analysis of 8000 hospital admissions for acute poisoning in a rural area of Sri Lanka. Clinical Toxicology (Phila), Vol. 44, No. 3, pp. 225-231. ISSN: 1556-3650. 
Williams G.M.; Kroes R. \& Munro I.C. (2000). Safety evaluation and risk assessment of the herbicide Roundup and its active ingredient, glyphosate, for humans. Regulatory Toxicology and Pharmacology, Vol. 31, No. 2, pp. 117-165. ISSN: 0273-2300. 


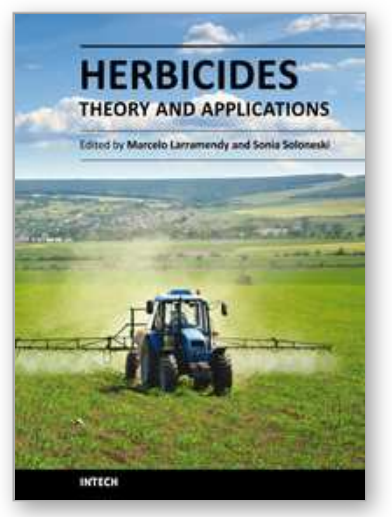

\author{
Herbicides, Theory and Applications \\ Edited by Prof. Marcelo Larramendy
}

ISBN 978-953-307-975-2

Hard cover, 610 pages

Publisher InTech

Published online 08, January, 2011

Published in print edition January, 2011

The content selected in Herbicides, Theory and Applications is intended to provide researchers, producers and consumers of herbicides an overview of the latest scientific achievements. Although we are dealing with many diverse and different topics, we have tried to compile this "raw material" into three major sections in search of clarity and order - Weed Control and Crop Management, Analytical Techniques of Herbicide Detection and Herbicide Toxicity and Further Applications. The editors hope that this book will continue to meet the expectations and needs of all interested in the methodology of use of herbicides, weed control as well as problems related to its use, abuse and misuse.

\title{
How to reference
}

In order to correctly reference this scholarly work, feel free to copy and paste the following:

Hsin-Ling Lee and How-Ran Guo (2011). The Hemodynamic Effects of the Formulation of GlyphosateSurfactant Herbicides, Herbicides, Theory and Applications, Prof. Marcelo Larramendy (Ed.), ISBN: 978-953307-975-2, InTech, Available from: http://www.intechopen.com/books/herbicides-theory-and-applications/thehemodynamic-effects-of-the-formulation-of-glyphosate-surfactant-herbicides

\section{INTECH}

open science | open minds

\section{InTech Europe}

University Campus STeP Ri

Slavka Krautzeka 83/A

51000 Rijeka, Croatia

Phone: +385 (51) 770447

Fax: +385 (51) 686166

www.intechopen.com

\section{InTech China}

Unit 405, Office Block, Hotel Equatorial Shanghai

No.65, Yan An Road (West), Shanghai, 200040, China

中国上海市延安西路65号上海国际贵都大饭店办公楼 405 单元

Phone: +86-21-62489820

Fax: $+86-21-62489821$ 
(C) 2011 The Author(s). Licensee IntechOpen. This chapter is distributed under the terms of the Creative Commons Attribution-NonCommercialShareAlike-3.0 License, which permits use, distribution and reproduction for non-commercial purposes, provided the original is properly cited and derivative works building on this content are distributed under the same license. 